A wide variety of initial medical treatment has been tried to improve retinal venous flow but the results have been unrewarding. ${ }^{6}{ }^{19-23}$ Long term management should centre on the implications of underlying cardiovascular disease-in particular, the identification and treatment of hypertension is paramount, given the evidence that treatment may reduce the severity of some of its complications. ${ }^{24} \mathrm{~A}$ similar approach to the treatment of hyperlipidaemia is also justified. ${ }^{25}$

Patients with hypertension, hyperlipidaemia, and low HDL-cholesterol concentrations are probably most at risk of recurrence and need intensive medical treatment to try to prevent this. In our view use of controlled studies of the effects of such treatment is difficult to justify on ethical grounds in view of the important prognostic implications of hypertension and hyperlipidaemia with respect to coronary and cerebrovascular disease. And our preliminary results with an aggressive therapeutic regimen aimed at individual abnormalities have been encouraging: in 400 patients presenting consecutively over five years with a single episode of retinal vein occlusion and treated intensively there was only a $1 \%$ rate of recurrence compared with the $10-15 \%$ in historical series.

Paul M Dodson Senior registrar in medicine

Clinical Investigation Unit,

Dudley Road Hospital,

Birmingham B18 7QH

Birmingham and Midland Eye Hospital, Birmingham B3 2NS

ERNA E KRITZINGER Consultant ophthalmic surgeon

Correspondence to: Dr Dodson.
1 Sorsby A. The incidence and causes of blindness in England and Wales 1963-1968. London: HMSO, 1976. (Reports on Public Health and Medical Subjects No 28.)

2 Rubinstein K, Jones EB. Retail vein occlusion: long term prospects, ten years' follow-up of one hundred and forty three patients. Brf Ophthalmol 1976;60:148-50.

3 Dodson PM, Kubicki AJ, Taylor KG, Kritzinger EE. Medical conditions underlying recurrence of retinal vein occlusion. BrF Ophthalmol 1985;69:493-6.

4 Klein BA. Occlusion of the centrral retinal vein: clinical importance of certain histo-pathologic observations. Am f Ophthalmol 1953;36:316-24.

5 Rabinowicz IM, Litman, Michaelson IC. Branch venous thrombosis-a pathological report. Trans Ophthalmol Soc UK 1968;88:191-210.

6 Kohner EM, Shilling JS. Retinal vein occlusion. In: Rose C, ed. London: Chapman and Hall, 1976:391-429.

7 Dodson PM, Kritzinger EE. Underlying medical conditions in young patients and ethnic differences in retinal vein occlusion. Trans Ophthalmol Soc UK 1985;104:114-19.

8 Chizek DJ, Franceschetti AT. Oral contraceptives: their side effects and ophthalmic manifestations. Surv Ophthalmol 1969;14:90-105.

9 Dodson PM, Galton DJ, Hamilton AM, Blach RK. Retinal vein occlusion and the prevalence of lipoprotein abnormalities. Brf Ophthalmol 1982;66:161-4.

10 Dodson PM, Shine B. Retinal vein occlusion: C-reactive protein and arterial hypertension. Acto Ophthalmol 1984;62:123-30.

11 Ring CP, Pearson TC, Sanders MD, Wetherley-Mein G. Viscosity and retinal vein occlusion. Brf Ophthalmol 1976;60:397-400.

12 Dodson PM, Westwick J, Marks G, Kakkar VV, Galton DJ. Beta-romboglobulin and platele factor 4 levels in retinal vein occlusion. Brf Ophthalmol 1983;67:143-6.

13 Peduzzi M, De Rosa V, Fonda S, Coccheri S. Fibrinolytic response to venostasis as a prognostic factor for recanalisation. Thromb Res 1981;24:105-18.

14 Ellis CJ, Hamer DB, Hunt RW, Lever AF, et al. Medical investigation of retinal vascular occlusion. Br Med f 1964; ii: 1093-8.

15 Laatikainen L, Kohner EM, Khoudry D, Blach RK. Panretinal photocoagulation in central retinal vein occlusion: a randomised con 1 iled clinical study. $B r f$ Ophthalmol 1977;61:741-53.

16 Branch Vein Occlusion Study Group. Argon laser scatter photocoagulation for prevention of neovascularisation and vitreous haemorrhage in branch vein occlusion: a randomised clinical trial. Arch Ophthalmol 1986;104:34-41.

17 Blach RK, Hitchings RA, Laatikainen L. Thrombotic glaucoma: prophylaxis and management. Trans Ophthalmol Soc UK 1977;97:275-9.

18 Branch Vein Occlusion Study Group. Argon laser photocoagulation for macular oedema in branch vein occlusion. Am f Ophthalmol 1984;98:271-82.

19 Klein BA, Olwin JH. A survey of the pathogenesis of retinal venous occlusion. Arch Ophthalmol 1956;56:207-47.

20 Kohner EM, Petit JE, Hamilton AM, Bulpitt CJ, Collery CT. Streptokinase in central retinal vein occlusion: a controlled clinical trial. BrMed f 1976;i:550-3.

21 Clements D, Elsby J, Smith W. Retinal vein occlusion. A comparative study of factors affecting the prognosis including a therapeutic trial of Atromid $\mathrm{S}$ in this condition. $\mathrm{Br} \mathcal{F}$ Ophthalmol 1968;52:111-16.

22 Hart CD, Sansers MD, Miller SJD. Benign retinal vasculitis. Clinical and fluorescein angiographic study. Brf Ophthalmol 1971;55:721-33.

23 Gent A, Ingram GIC, Arocha-pinango Ch, Fenton P, Buckley RJ. Central retinal vein thrombosis; serial treatment with defibrination, aspirin and plasminotrophic drugs. Thromb Res 1979;14: 61-6.

24 Multiple Risk Factor Intervention Trial Research Group. Multiple risk factor intervention trial; risk factor changes and mortality results. JAMA 1982;248:1465-77.

25 Lipid Research Clinics Program. Primary prevention trial results. $尹 A M A$ 1984;251:365-74.

\title{
Testing paternity: traditional methods usually adequate
}

Recent publicity on using DNA fingerprinting - a genetic identification technique-to settle paternity problems has led to many inquiries from patients in paternity disputes. We are concerned that many doctors do not seem to understand the potential of the long established blood grouping tests to settle disputes: in $97-99 \%$ of cases they can provide proof of non-paternity where the father has been wrongly named. Additional tests are then unnecessary. In one in six cases submitted to two centres in 1986 proof was provided that the putative father was not the child's biological father.

Blood group testing also offers valuable evidence that helps to establish paternity in many cases. When it cannot be proved that the putative father is not the father then a mathematical assessment is made of the chance that he is the father. One international system is the paternity index, which is the ratio of the chance the putative father has of producing in one sperm the genes required to father the child to the chance of him doing so if he is unrelated to the child. The index gives values ranging from less than 10 to one to up to many thousands to one, and these high values are virtual proof of paternity.
The paternity index (PI) may be converted to a percentage relative chance of paternity $(\mathrm{RCP})$ using the formula: $R C P=$ $\mathrm{PI} /(\mathrm{PI}+1)$. Thus a paternity index of $20: 1$ gives a relative chance of paternity of $95 \%$; paternity indices above $100: 1$ give relative chances of paternity above $99 \%$. When the index is higher than this further increases make little difference to the relative chance of paternity. Thus an index of 1000:1 gives a relative chance of paternity of $99.9 \%$ (virtual proof of paternity) and the figure is increased by only $0.09 \%$ if the index reaches $10000: 1$.

In a small number of cases where the paternity index is less than 10:1 (relative chance of paternity less than 90\%) additional tests like DNA fingerprinting are necessary. But usually traditional blood testing will settle the question.

BARbara E DODD Emeritus professor

P J LINCOLN

Blood Group Serology, Senior lecturer

London Hospital Medical College,

London E1 2AD 